\title{
THE ORGANISING MODEL IN AUSTRALIA:
}

\section{A REASSESSMENT}

\author{
BRADLEY BOWDEN
}

Throughout the Anglo-Saxon world the 'organising model' has become the key union strategy for reversing membership decline. This article, however, argues that this model is conceptually flawed, in that it overlooks the significance of structural factors and strategies directed towards the regulation of occupational labour markets. In the absence of a system of industry or occupation-wide regulation even the best organised workplaces are exposed to de-unionisation. Sixteen years after its Australian adoption there is little evidence that the organising model has had any meaningful impact.

The diminished influence of trade unions, manifested most visibly in declining union density, is one of the most significant industrial relations issues of our time. In Australia, 49 percent of the workforce belonged to a union in 1982. Twenty-five years later, only 18.9 percent held a union ticket (ABS 2008a). By way of comparison, in 2007 a mere 12.1 percent of the United States' workforce was unionised. In 1975, 28.5 percent had been union members (Bureau of Labor Statistics 2008). In Canada, union members comprised 29.7 percent of the workforce in 2007, compared to 38 percent in 1981 (Statistics Canada 2007). In the United Kingdom, union density fell from 55 percent in the late 1970s to 28 percent in 2007 (Mercer and Notley, 2008: 3).

Within the Anglo-Saxon world, the union response to this decline has hinged upon what has become known as the 'organising model'. First developed in the United States (US) during the late 1980s, the organising model was embraced by Australian and New Zealand unions in 1993-94 (Griffin and Moors 2004; Walsh and Crawford, 2003). British unions endorsed the model in 1996 (Fairbrother and Stewart 2003). In judging the effectiveness of the organising model in the Australian context, Peetz (2006: 163) argues that the 'tide' was 'turned back.' Griffin (2007: 559) observes that, 'organizing ... remains the key strategy of Australian unions.'

Industrial relations academics have been forceful advocates of the organising model (Banks and Metzgar 1989; Conrow 1991; Bronfenbrenner 1997 and 2003; Juravic and Bronfenbrenner 1998; Peetz 2006; Peetz, Pocock and Houghton 2007; Cooper 2001 and 2003; Fairborther and Yates 2003; Oxenbridge 2003). Supporters of

\footnotetext{
Associate Professor, Department of Employment Relations, Griffith Business School, Griffith University and Adjunct Professor of Management, Central Queensland University. Correspondence to: b.bowden@cqu.edu.au.
} 
the organising model argue that past patterns of membership representation have been a major factor in union decline, creating a 'servicing model' in which workers became passive recipients of industrial representation. To overcome this legacy, it is believed, workplace organisation and activism must be made a priority, so as to 'empower' local members, and provide them with the ability 'to solve problems themselves, as opposed to having the union office - away from the workplace - solve it for them' (Peetz 2006: 164).

The organising model has, however, faced resistance within the union movement itself. Cooper (2001: 432-33)page numbers?), in studying one white-collar union, found that 'each step of the change process was contested'. Surveys of Australian Council of Trade Unions (ACTU) Congress delegates, conducted during 1995 and 1997, recorded that only 43.7 percent of delegates who completed the survey rated Organising Works - the vehicle for developing the organising model - as a success (Gahan and Bell 1999: 19). Resistance to the organising model has also been reported in research on the United States, New Zealand and the United Kingdom (Voss and Sherman 2003; Oxenbridge 2003; Heery, Simms, Simpson, Delbridge and Salmon 2000).

While the organising model has faced union opposition, it has not been subject to much in the way of critical academic review. To the extent that scepticism has been expressed, it has - until recently - largely related to the practicalities of implementation (Griffin, Small and Svenson 2003; Heery et al 2000; Fletcher and Hurd 1998) rather than to its underlying merits. A more critical approach is, however, beginning to emerge. Barton, Snell and Fairbrother (2008: 20) have recently observed that, in advocating workplace activism as the solution to the union movement's woes, researchers have tended to 'ignore' the 'structural realities' that undermine union strength. They also note that there is in fact no clear correlation between various union strategies on the one hand and membership retention and growth on the other. Some unions who have adopted a 'business unionism' model (built around cooperation with employers) have 'done better than those who have adopted the organising model’ (Barton et al 2008: 21).

This article contributes to the emerging critique of the organising model, suggesting that we need to return to some basic frames of reference in considering union organising strategies. Historically, unions existed for the purpose of regulating occupational labour markets. Everywhere this involved two broad strategies. First, unions sought to restrict entry into each occupation or industry. This task was easier for craft unionists (who sought to ensure that only workers who had completed appropriate training were offered employment) than for unions of unskilled workers (who had to enforce a closed 'union shop' in order to exercise labour market control). Second, unions sought to impose standardised employment conditions in every workplace, realising that lower standards in one compromised those businesses that paid the union rate. In studying the origins of United States' unions, Perlman and Taft (1966: 10) noted that organising was undertaken to enforce 'laws' that were 
'mandatory upon the individual employer and employee.' Unions did not establish local branches so that workers could negotiate their own wages and conditions but, as the Webbs (1902: 201) observed, to ensure 'uniformity' and 'to guard the local interests of the trade'.

While no one interested in union survival would argue against workplace organisation and recruitment this paper nevertheless argues that the organising model is conceptually flawed. An 'organising' strategy that focuses on simply building up workplace strength cannot, in itself, redress market-created power imbalances. To be effective, workplace organisation must, as it was in the past, be subject to centralised and coordinated campaigns with an industry or occupational focus. Empirically, there is no evidence to suggest that, since it was first adopted by many Australian unions, the organising model has had any meaningful impact. On the contrary, union density and absolute membership continue to fall. The best predictor of high union density in Australia is not a union's workplace organising ability but rather - as in the past - its capacity to exert control over labour market outcomes. In August 2007, there were only seven industry sub-sectors where union density remained above 40 percent - rail transport, air and space transport, electricity, preschool and school education, public order and safety, hospitals, and coal mining (ABS 2008a). Each was characterised by substantial barriers to entry for new competitors, and union-endorsed restrictions or training qualifications on labour entry (in coal mining the recent collapse in union density followed on from the demise of such restrictions). This pattern suggests that strategies directed towards increased labour market regulation at the industry or occupational level will provide a better guarantee for union survival than workplace organising campaigns.

\section{Patterns of Union Decline in Australia}

Union decline in Australia, as elsewhere, is a complex matter involving many interrelated factors, including structural changes in the economy, increased global competition, the growth in various categories of contingent employment, and industrial relations deregulation (Griffin and Svensen 1996; Alexander, Green and Wilson 1998; Gahan and Bell 1999; Wooden 1999; Griffin, Small and Svenson 2003; Griffin 2007; Peetz, 1998 2006). Much attention has focused on the supposed dependency of the Australian union movement on the systems of compulsory conciliation and arbitration that shaped industrial relations prior to the late 1980s, it being argued that within this framework 'unions grew as wards of the state rather than as independent working-class organizations' (Fairbrother and Yates 2003: 6. Also see Howard 1977; Peetz, 1998 2006; Pocock 1998. For a contrary view, see Gahan 1996).

What is often overlooked in current debates about union decline in Australia is that it is not a recent phenomenon, and that it long predated the decline of the award system, whereby industrial regulation was imposed by state and federal tribunals. Like other public institutions, the waxing and waning of union strength has reflected historic forces over which unions had limited control (structural changes in the labour 
force, changes in patterns of work organisation and the level of global competition). Admittedly any Australian linear study has to recognise changes in the compilation of union membership statistics. Prior to 1976, such statistics were based on the membership figures provided by unions themselves. It is widely recognised these figures probably overstated the number of individuals who held a union ticket given that some workers held multiple jobs (and union tickets) [see below - citation]. Since 1976, union membership figures have been based on household surveys, which may understate real membership levels [Deery and Plowman, 1991: 227)citation]. Such limitations aside it would nevertheless appear that the peak year for union density was 1948 when 64.9 percent of wage and salary earners belonged to a union (in Queensland 81.1 per cent were unionists in that year). In terms of union density the 1960s was a grim decade for unionism, as many traditional blue-collar jobs in mining, the waterfront and the rural sector disappeared. Nationally, union density declined from 58 to 49 percent between 1960 and 1969. In Queensland the loss of rural jobs saw union density fall by a massive 19 percent during the 1960s (ABS 1948-75.).

While national density levels rebounded by 7 per cent between 1969 and 1975 as unions gained a mass following among public servants and white-collar professionals, structural factors undercut this revival. Manufacturing, which provided jobs to more than 28 percent of the workforce in the early 1960s,accounted for only 10 percent of total employment in 2006-07. By this latter date, the retail sector (14 percent), property and business services (12 percent) and community services (10 percent), all employed more people. In the decade to 2006-07, the proportion of employees engaged part-time, rather than full-time, rose from 19 to 28 percent (ABS, 2008b). Increases in other forms of contingent labour, including self-employed contractors, also contributed to labour market change (Vandenheuvel and Wooden 1995: 263).

In the early 1980s unions put much store in the Prices and Incomes Accord, signed between the Australian Council of Trade Unions (ACTU) and the Labor Party. The unions were worried about structural changes in the economy that had contributed to a heavy loss of unionised jobs. The Prices and Incomes Accord was supposed to overcome this problem by fostering industry and protecting manufacturing jobs. However, the Hawke-Keating Governments pursued a policy of economic liberalisation. From 1986 onwards, Australia witnessed a series of radical industrial relations changes. Initially awards were 'restructured' to link wages increases to productivity improvements. Then in 1991, enterprise bargaining was introduced. Nonunion collective agreements followed in 1993. All of these changes were overseen by Labor Governments. The election of the Howard-led coalition in 1996 produced more overtly anti-union legislation, providing for individual Australian Workplace Agreements (AWAs). ${ }^{1}$ By 2006, only 19 percent of all workers had their wages set by awards, while 38.1 percent were under collective agreements (only 3.1 percent were on AWAs or their equivalent). There were, however, marked differences between the private and public sectors. Whereas 92.9 percent of public sector workers were under

1 For a detailed overview of these developments, see Dabschek, (2001). 
a collective agreement, only 24.4 percent of private sector workers were engaged under such arrangements (ABS 2008b: 258).

From the preceding discussion it is useful to compare the rate at which union density fell in the ten years to 1996 (the 'Labor' years) with the ensuing 'Howard' decade. As Figure 1 indicates, compared with the 'Labor' years, the rate of decline moderated in the 'Howard' decade. Union density dropped by 14.5 points (from 45.6 to 31.1 percent) under Labor. In the Howard decade it fell 10.8 points (to 20.3 percent). In both decades, the rate of decline was most marked in the public sector. Under Labor, public sector density fell by 15.2 points (from 70.6 to 55.4 percent) whereas in the private sector it fell by 10.5 points (from 34.5 to 24 percent). Under Howard, public sector density dropped by 12.8 points to 42.6 percent. Private sector density declined 8.8 points to 15.2 percent (ABS 2007a and 2007b). These results suggest that Howard's legislation was not the main factor in union decline. It also indicates that the almost universal coverage of the public sector by collective agreements did little to maintain union membership. The Australian public sector has not acted as the bastion of union strength that is assumed to be the Anglo-Saxon norm (Haynes, Boxall and Mackay 2006; Pocock 1998).

Figure 1: Declining union density, 1986-1996, 1996-2006

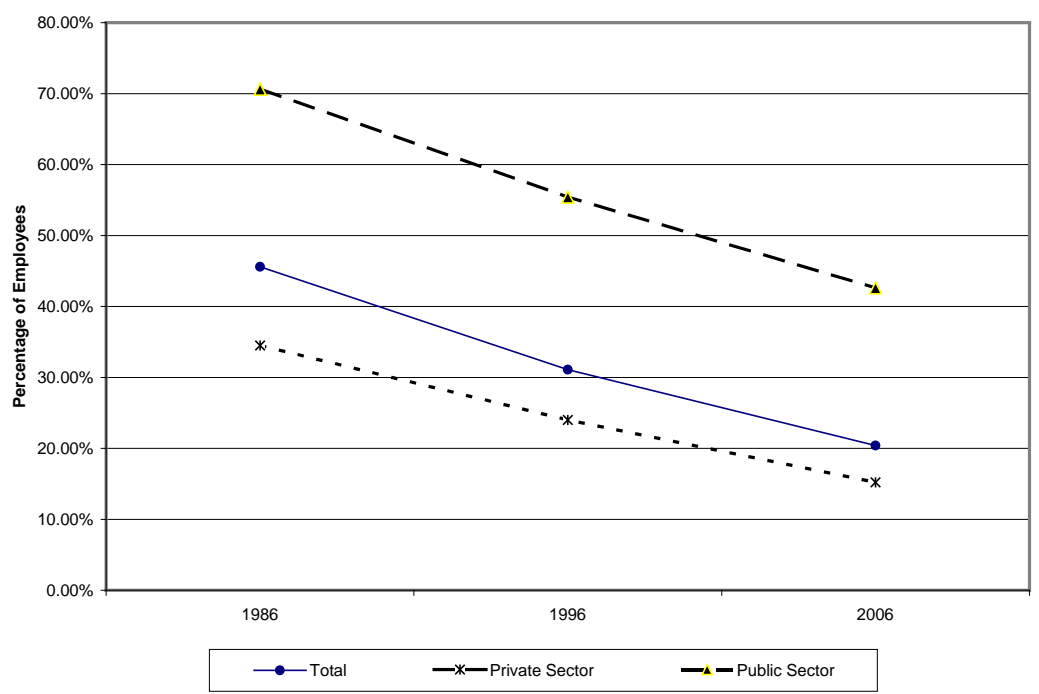

Source: ABS 6310.0, 1996, 2006

The marked decline in public sector union strength is emphasised when we examine absolute numbers. As Figure 2 reveals, even in 1992 there were more unionists in the private sector than the public sector. The gap has widened since. The union movement lost 812,400 members between 1992 and 2007. Of these, 455,500 
were lost in the public sector (ABS, 2007a, 2008a). The union movement thus suffered more direct harm from changes in public sector employment than from aggressive private sector management strategies.

Figure 2: Number of Union Members (Public and Private Sectors), 1992-2007

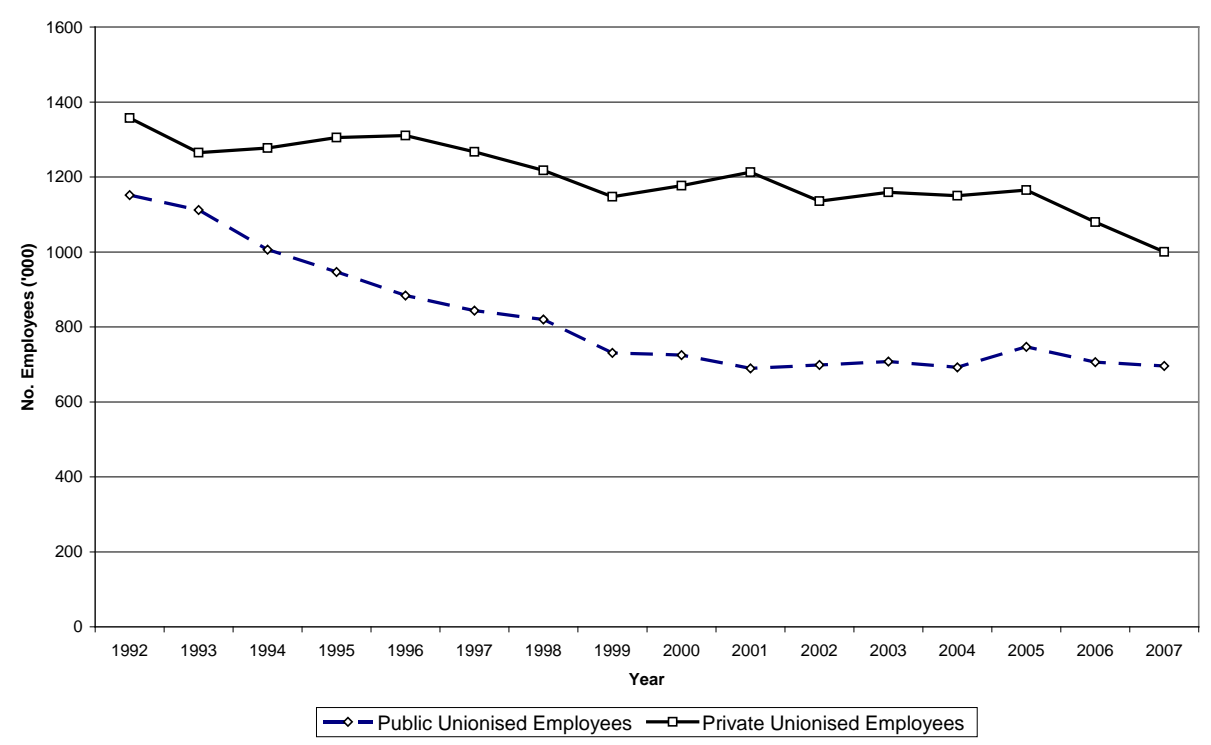

Source: ABS Trade Union Membership Time Series, 2007; ABS, Cat No 6310.0, 2008

When, as in Figure 3, we factor in non-union workers in both sectors, two points stand out. In the public sector, the fall in union density largely reflects the displacement of unionists by non-unionists. The total number employed in the sector in $2007(1,692,900)$ was little different from $1992(1,716,700)$. By contrast, declining union density in the private sector was primarily due to the addition of more than three million non-union workers during the same period. Thus, while there were still one million private sector unionists in 2007, there were 6.3 million non-unionists (ABS 2007a and 2008a).

Figure 3: Total Employees (Union, Non-Union): Private and Public Sector, 1992-2007 


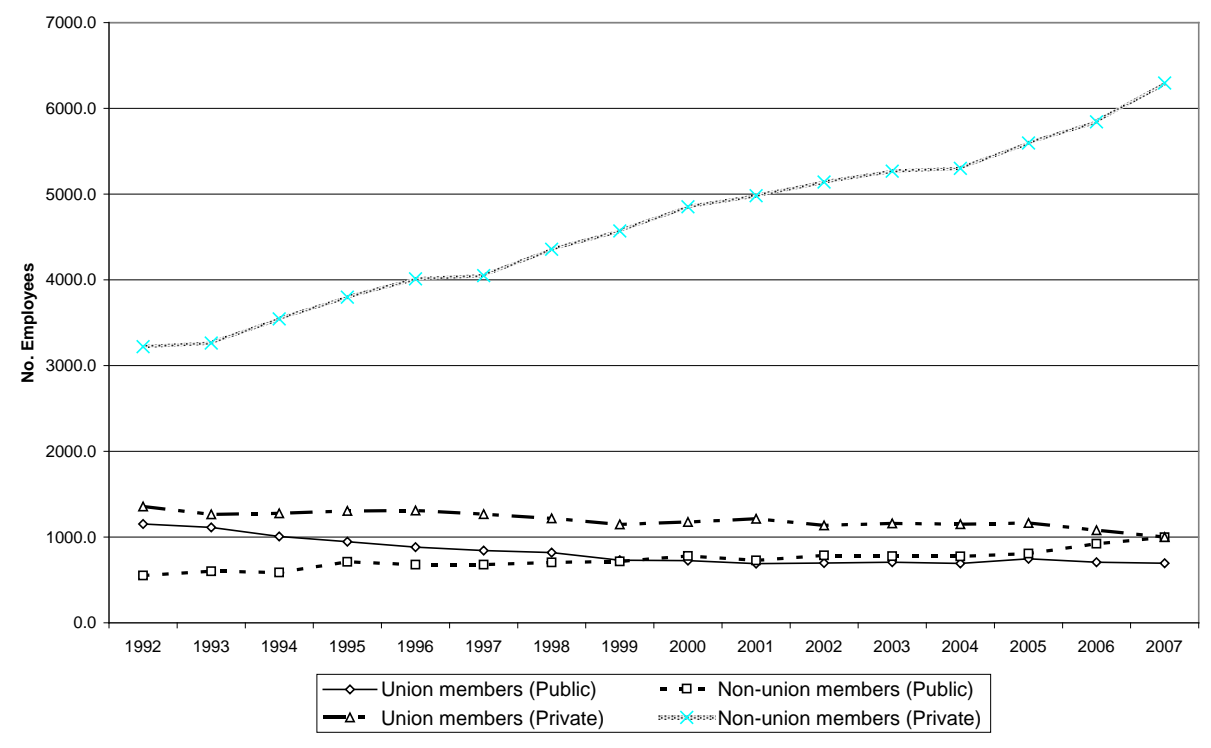

Source: ABS Trade Union Membership Time Series, 2007; ABS, Cat No 6310.0, 2008

If possession of a union card is one indicator of support for unionism, so too is a willingness to join with fellow workers in industrial action. It has been argued that conciliation and arbitration systems adopted in Australasia had a particularly adverse effect on union activism (Peetz 2006; Peetz et al 2007; Fairbrother and Yates 2003; Walsh and Crawford 2003). The organising model, it was hoped, would overcome this supposed legacy. However, Figure 4 indicates that the introduction of enterprise bargaining in 1991 was associated with a dramatic fall in industrial disputation. By 2007, passivity prevailed (ABS 2008c). 
Figure 4: Working days lost due to industrial disputes, 1986-2007

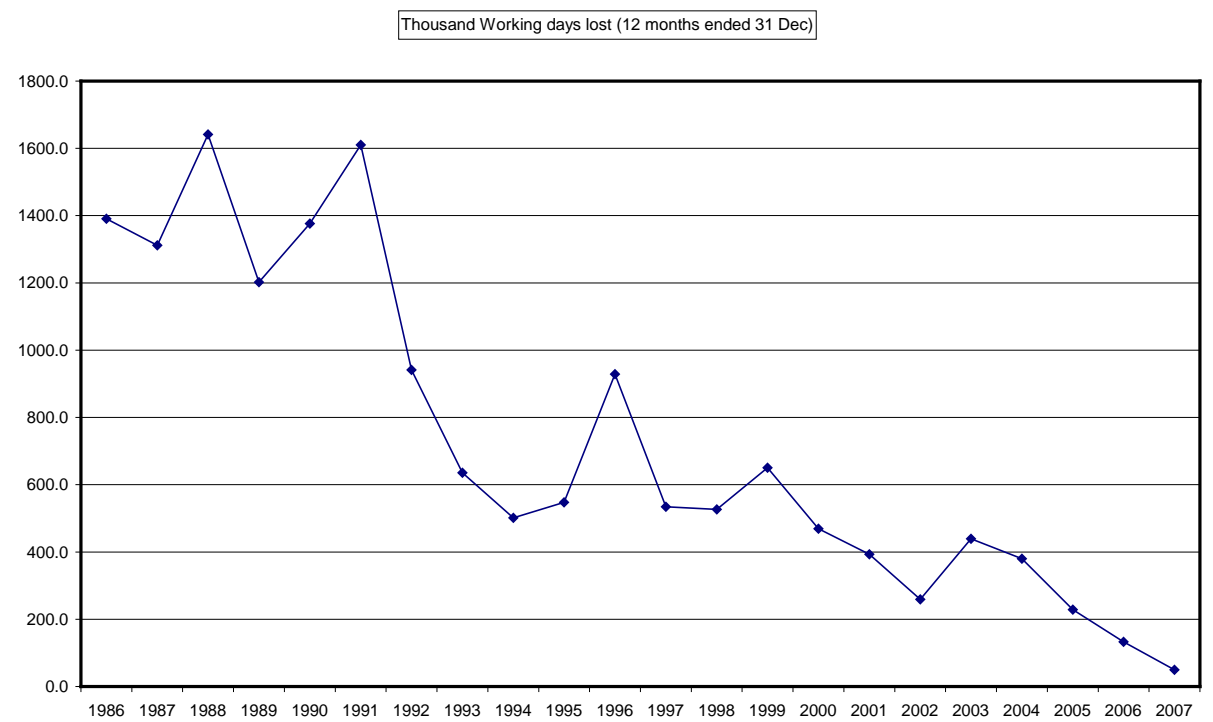

Source: ABS Trade Union Membership Time Series, 2007; ABS, Cat No 6310.0, 2008

To sum up, union decline in Australia has been a long historical process. Much of this decline must be attributed to structural factors. However, since the mid-1980s the progressive dismantling of the previous centralised system of industrial relations has also had a major effect. Given the pattern of union decline in Australia, to what extent has the 'organising' literature provided the basis for a coherent strategy capable of redressing the above trends?

\section{The 'Organising' Literature}

By the early 1990s it was evident that, throughout the industrialised world, the patterns of bargaining and union representation which had characterised the post-1945 world were being undercut by economic deregulation, increased competition and new patterns of work organisation. Even where unions maintained a substantive presence they struggled to maintain systems of industry-wide regulation, as individual firms sought to gain improved workplace efficiencies in order to compete more effectively. Two broad strategic responses emerged. The first of these emphasised the importance of 'partnerships' between unions and enterprises at the workplace level in order to enhance productivity, jobs and skill formation (Kochan, Katz, McKersie 1986; Katz and Sabel 1985; Turner 1991; Mathews 1989). This 'partnership' approach characterised the initial ACTU response to economic and industrial relations deregulation. By the early 1990s, however, the introduction of enterprise bargaining and the acceleration in the rate of union decline helped facilitate growing Australian 
interest in what has come to be called the organising model, whereby union revival strategies are premised upon increased worker activism and workplace organising.

Central to the advocacy of a new organising model was the belief that, far from being simply the victims of structural changes in the economy and anti-union legislation, unions were culpable for their own decline. As Bronfenbrenner et al (1998: 5) observed: 'Unions themselves bear significant responsibility for their own decline.' Unions, it was argued (Bronfrenbrenner at al 1998; Bronfrenbrenner 2003; Fletcher and Hurd 1998; Danford, Richardson and Upchurch 2003; Schenk 2003; Peetz 2006), had put few resources into either 'internal organising' (the organisation of workplaces where unions had an established presence) or 'external organising' (the organisation of workplaces that had few if any union members). The latter failure, it has been observed (Bronfrenbrenner at al 1998), left 'whole sectors of the economy... untouched by union activity'.

While the organising model has been enthusiastically advocated as a strategy for reversing union decline, it is a somewhat fluid and ill-defined conceptual framework. It is nevertheless fair to say that advocates of the organising model agree that if union revival is to occur it requires, as a minimum, the following five changes to union procedures:

(i) replacing top-down union decision-making structures that have alienated workers with more democratic processes that give workers a greater say in workplace bargaining arrangements;

(ii) placing a greater emphasis on recruiting new members (external organising), rather than just servicing existing membership;

(iii) facilitating effective workplace activism and organisation so that workers are empowered to undertake activities on their own behalf, rather than simply relying on paid union officials (internal organising);

(iv) ensuring that workplace activists have the skills and resources to manage their own affairs; and

(v) establishing networks that will link activists in different workplaces. ${ }^{2}$

Although the above principles are widely considered as necessary to the process of union revival not all believe that they are sufficient. Numerous scholars (Pocock 1998; Voss and Sherman 2003; Schenk 2003, Danford et al 2003; Fletcher and Hurd 1998; Hurd 2004) argue that the organising model will only succeed if it is extended to include support for 'social unionism', in which unionists ally themselves with others in pursuit of wider social objectives. Such a strategy, it is believed, will provide

2 For a representative view of the key features of the organising model in different national contexts see: (Bronfenbrenner 1997 and 2003; Cooper 2001 and 2003; Fairbrother and Yates 2003; Fairbrother 2000; Hurd 2004) 
the basis for unionism to escape from its increasingly marginalised social and political position as alliances are built with 'community coalitions' around issues such as health care, the state of the environment and the socially adverse effects of corporate behaviour (Schenk 2003: 248-49; Danford et al 2003: 11). In outlining the benefits of union strategies that seek to build alliances with consumer and community groups, Mareschai (2006: 26) contends that: 'One overarching objective of unions is to secure access to government leaders so that they may shape public policy on behalf of union members'.

If the organising model has promised much, even its most ardent advocates would concede that results have fallen short of anticipated gains. Many failings are attributed to problems in implementing the organising model within a union population unaccustomed to its precepts. The model has, by common consent, been implemented in a 'top-down' manner (Griffin and Moors 2004; Cooper 2001; Fletcher and Hurd 1998; Peetz et al 2007). Where the organising model has been adopted, it has typically followed the election of a new leadership team. The supply of organisers entrusted with implementing the organising model initially came from the new union organising academies. Few had industrial experience. The implementation of the model has also been 'patchy', beset by difficulties and opposition (Peetz et al 2007; Heery et al 2000; Oxenbridge 2003). Among supporters of the organising model, this has been largely attributed to continuing support for the old 'servicing model' among both union officials and rank-and-file members (Oxenbridge 2003; Cooper 2001; Voss and Sherman 2003; Pocock 1998). The commitment of resources to organising the unorganised (external organising) has faced opposition from existing union members who feel that their union dues should be spent on looking after their needs, rather than those who do not hold a current union ticket (Fletcher and Hurd 1998: 49).

While it is possible to argue that the inability of the organising model to halt the overall decline in union membership is attributable to faulty implementation, its conceptual foundations have also been challenged. Griffin et al (2003: 95) suggest that the 'central tenet of the organising model' - the preparedness of ordinary workers to become union activists - is 'unrealistic'. In the United States, Fletcher and Hurd (1998: 52, 43) also concluded that, in most situations, the model was 'not realistic and is not good strategy' as the 'typical member' was 'either timid or disinterested'. Even where new external organising campaigns were successful, they were often circumvented by employers with relative ease. As Ness (1998: 101) observed in the US garment industry, 'Once a shop is organized, manufacturers can switch production to lower-cost producers'. In Australia, Probert and Ewer (2003: 111, 114) have suggested that strategies aimed at a 'revitalization of craft-organizing practices which focus on exploiting occupational labour shortages - may be more effective than 'the workplace organizing model favoured by the ACTU'. Barton et al (2008: 17), after comparing the membership trends of a number of unions, conclude that: 
... some of the very successful unions did not consciously embrace an organising model, whereas other unions ... articulated an organising approach and rhetoric without apparent success as defined by membership levels.

In the United States, where the organising model had its roots, enthusiasm for its prescriptions for renewal has waned. By 2006, Hurd (2006: 208) was describing the organising model as a 'failure', whose demise provided a salutary lesson for those 'in other countries who have been impressed by the promise of narrowly conceived revitalisation.' While Hurd (2004, 2006) believes that union revival requires a more coherent social vision there is no guarantee that a firmer embrace of 'social unionism' will return any greater dividends. Historically, union support for social change has proved something of a double-edged sword. Campaigns that advocated greater social equality and improved workplace and political rights for minority groups, have given the labour movement a sense of vibrancy and attracted support from women, various ethnic groups and the economically disadvantaged [Voss and Sherman 2003; Schenk 2003; Hurd 2004citation?]. But such campaigns have also tended to produce a counter-offensive from more conservative sections of the workforce, and from those who believe that unions should confine their activities to industrial issues [citation?]. In Australia the underlying conservatism of much of the workforce was most forcibly demonstrated during the 1940s and 1950s, when the Catholic-based 'Movement' was organised to successfully counter communist influence within the union movement [Santamaria 1981citation]. The capacity of 'social unionism' to deliver improved outcomes to the labour movement is also constrained by long-established political institutions and relationships. These constraints are most pronounced in those nations where 'Labour' (Labor) parties have been established to represent union interests (most notably, the United Kingdom, New Zealand and Australia). In the past Labour/Labor governments have delivered the union movement favourable industrial and social legislation. But in recent decades they have invariably supported the policies of economic and labour market 'deregulation' that have contributed to union decline. However, any attempt to organise widespread community campaigns to exert pressure on Labour/Labor governments, or to establish alternative political parties sympathetic to union interests, risks a damaging (and possibly fatal) split in the labour movement's ranks.

One of the most problematic features of the organising model is found in its lack of ideological clarity, and an associated vagueness as to the ultimate objective of union organising activities. Such failings were identified by Fletcher and Hurd (1998: 4852) over a decade ago, when they observed that in the United States the organising model was applied with different ends in mind in different union Locals. In some places the organising model was focused on 'empowering individual members'. In others issues of 'social and economic justice' assumed centre stage. More broadly, Fletcher and Hurd (1998: 52) noted a confusion as to the ultimate strategic objective of the organising model (also see Hurd 2004). The relevance of the organising model 
becomes particularly problematic if the re-regulation of occupational and industrial labour markets is seen as the central goal of union activity. If this is seen as the ultimate goal (and is difficult to see how unionism can gain long-term relevance without the achievement of this objective) then unions must (re-)develop the capacity to assert uniform wages and conditions across industries and occupations. This, as the Webbs long ago realised, requires a professional union officialdom capable of asserting a strong measure of centralised control over bargaining outcomes. This, in turn, requires a restraint of independent membership activities that may lead to one workplace negotiating employment relationships at odds with those sought by the union as a whole.

Despite the growing criticism in the international literature, the organising model's impact has generally been portrayed in more favourable terms in Australia. At face value, this new approach appeared well-suited to the crisis within which Australian unionism found itself. While Australian unions had long demonstrated a capacity for industrial action, their campaigns were invariably centrally directed. Relatively few workplaces were experienced at negotiating their own industrial outcomes (Alexander et al 1998; Callus, Moorehead, Cully and Buchanan 1991). It has been stated that, from 1999, the new organising focus had a dramatic effect, halting the loss in union numbers (Peetz 2006: 163; Griffin 2007: 559). Even Barton et al (2008: 8), despite a more critical appraisal, observe that the fall in total union membership 'has begun to level out'. How credible are these claims? It is certainly true, as Figure 2 indicates, that 1999 saw a levelling off in the rate of decline in absolute union numbers. Of the 812,400 members lost to the union movement between 1992 and 2007, only 181,800 were lost after 1999. But the overall growth in the labour market was also much faster after 1999 than previously. More than 1.6 million new jobs were created between 1999 and 2007. In the preceding period (1992-99) only 900,000 new positions were created (ABS 2007a and 2008a). The election of the Rudd Labor Government in 2007 also had little immediate impact on trade union fortunes. While absolute membership increased by three per cent in 2008 this was largely attributable to the growth in the size of the workforce. The percentage of the workforce that held a union ticket remained static at 19 per cent (ABS 2009).By 2009 many unions were reporting major gains in terms of recruitment; however there was little evidence that such organising gains had resulted in a significant increase in overall union density. As in the past, structural changes in the economy and the labour market offset the benefits of many organising campaigns. In 2008-09, the Finance Sector Union, for example, recruited 8,000 new members. But it also lost 16,000 due to the effects of outsourcing and redundancies. The Community and Public Sector Union also recruited 8,000 members in the same period. But all these gains were negated by resignations and redundancies (Hannan 2009a: 6) 
The fact that the union movement could not even maintain its membership during a period when overall employment grew by 23 percent is hardly suggestive of success. ${ }^{3}$ Of perhaps even greater concern for the union movement was that, during this period of supposed stabilisation, density levels began to collapse among some of its best organised sections. Previously, research had predicted that high levels of workplace organisation would protect unions from a loss of members (Alexander et al 1998; Peetz 2006; Pocock 1998). This prediction did not eventuate. Between 1996 and 2007, union density levels dropped by 28.6 percentage points in coal mining (to 56.6 percent), 20.7 points in electricity and gas (to 47.7 percent) and 15.4 points among railway workers (to 69.5 percent). In 2000, there were, for the first time, more nonunionists than unionists in the public sector (ABS 2008a). Even where unions were well-established, workers were opting not to join, or letting their membership lapse.

Contrary to the claims made by supporters of the organising model, its adoption appears to have had no discernable impact on the rate of union decline. ${ }^{4}$ The 'organising' literature also fails to explain the rapid fall in public sector union membership over the period in which the organising model has been in place. Indeed, this research appears to have been largely blind to these developments.

The organising model appears, at first glance, more comfortable in explaining the rapid collapse in union membership after 1991. Australian unions were too dependent on the arbitration system (Howard 1977 and 1983). ${ }^{5}$ This induced passivity and an inability to organize. It is certainly the case that union density fell abruptly when the centralised system was dismantled. ${ }^{6}$ But trends in industrial disputation (Figure 4) indicate much higher levels of worker militancy under the centralised system. Industrial passivity, therefore, was not a product of the arbitration system. It followed on from its destruction.

To sum up, there is little evidence that the organising model has been a panacea for the Australian union movement's woes. Its most notable claim - to have halted the decline in union membership - has little credibility. The steady retreat of membership in the public sector, and in key private sector strongholds, casts doubt on the assumption that workplace organisation can protect unions from decline.

3 Between 1999 and 2007, the Australian labour force grew by 23 percent from 7.3 million to 9 million persons [ABS 2000: 3; ABS 2008a: 3 citation].

4 One possible argument is that the decline in membership may have been worse in if the organising model had not been in place. However, the reality has been that, during the period it was official ACTU policy, union density has deteriorated dramatically.

5 For a critique of the dependency theory, see Gahan (1996).

6 It should be noted that union decline in Australia was not as dramatic as that following the passage of the more radical Employment Contracts Act 1991 in New Zealand. Whereas the Australian award system suffered what Dabscheck (2001: 276-93 page number) has called a 'slow and agonising death' the New Zealand changes (both legal and industrial) were concentrated in a much shorter period of time. For an account of the New Zealand changes, see Walsh and Crawford (2003). 


\section{Discussion: Reconsidering Union Organising}

In looking for the reasons for the decline in Australian union strength, the early 1990s are clearly critical years. This was the period when enterprise bargaining displaced awards as the principal mechanism for determining employment conditions. Workers' capacity, or willingness, to engage in industrial action collapsed, never to recover. Between 1990 and 1996 the union movement lost more than 465,300 members (almost half the total loss suffered between 1990 and 2007). As noted earlier, it has been widely argued that strong workplace organisation, and a tradition of workplace bargaining, provided unions with a capacity to respond effectively to this changed industrial environment (Alexander et al 1998; Callus et al 1991). The experiences of the coal mining unions - the most notable of which is the Construction Forestry Mining and Energy Union (CFMEU) - have been seen as proof of this thesis. While workers in the Western Australian iron industry were largely lost to the union movement in the 1980s, in the coal sector the density rate still stood at 85.2 percent in 1996. Writing at a time when, paradoxically, coal mining unionism was in marked decline, Peetz (2006: 175) attributed the CFMEU's strength to a strong 'delegate structure' and 'a history of workplace-based bargaining that long pre-dated the rise of “enterprise bargaining".' By 2008, however, there were 16,500 non-unionists among Australia's 37,200 coal miners (ABS,2008a: 37).

Although much has been made of coal miners' traditions of workplace organisation, in truth the industry has been subject to greater industrial regulation than any other sector. Between 1946 and 1995, the coal industry was not even part of the mainstream industrial relations system. Instead, employment relations were subject to the oversight of the Coal Industrial Tribunal (CIT). While the coal industry's centralised system of industrial regulation survived, so too did the workplace organisation of the unions. When the system of industry-wide regulation unravelled, however, unions found themselves in a difficult position. In 1987, the CIT acceded to the employers' demands for 'continuous production'. Twelve-hour shifts (typically worked on the basis of four days on, four days off) became the norm. These arrangements eroded the integrity of the communities that underpinned the strength of the coal unions as miners began commuting to work from distant locations (Di Milia and Bowden, 2007). From 1996 employers, no longer bound by the CIT's dictates, began repudiating the agreements that had restricted their use of contractors. In Queensland, contractors made up 7.5 percent of the coal mining workforce in 1996. Six years later, they made up 30.2 percent (Bowden 2003). Contractors typically sub-contracted, making recruitment much more difficult. As the industry expanded during the post2002 'boom', the unions were unable to claw their way back.

The supposed correlation between workplace union activism and membership retention and growth is also disputed by the findings of Barton et al (2008). As part of their analysis of Australian union strategies, these researchers compared aggregate membership trends in the Australian Manufacturing Workers Union (AMWU), a 
union 'with a strong activist base', with the Australian Workers Union (AWU) - a body noted for preferring a 'partnership approach' with employers. They conclude that: 'The AMWU has witnessed a more stark decline in union membership over the past decade than the AWU' (Barton et al 2008: 11).

The recent catastrophic decline in union density in the coal industry - and the decline of the AMWU - highlights how advocates of the organising model, in emphasising a workplace focus, have based their prescriptions for union renewal on questionable assumptions. Rather than union strength resting on workplace organisation, it is more likely that union strength (and its workplace manifestations) reflects favourable labour market circumstances. If unions lose the capacity to regulate the overall occupational labour market, then their workplace influence will inevitably wane. Many of the problems faced by workers since the mid-1980s down-sizing, firm restructures, out-sourcing, structural changes in the economy were not amenable to workplace solutions. This was particularly the case in the public sector where the protection of employment security requires a whole of sector approach. Between 1992 and 1997, public sector employment fell by 205,100. When new jobs were added, they were increasingly part-time. In 1992, part-time workers made up 17 percent of the public sector workforce. Fifteen years later, they comprised 26.2 percent. These two trends - the massive down-sizing of the early 1990s and the steady increase in the percentage of part-timers - were the primary reasons why union density fell so hard in the public sector. As late as 2005, most full-time public sector employees were still in a union. But, even in 1992, most part-timers were not (ABS 2007a and 2008a).

If the organising model was correct, we would expect to find that unionism survived best in those sectors noted for their traditions of workplace recruitment and bargaining. However, the evidence contradicts this proposition. In 2007, education was the most highly unionised industry (38.9 percent of those employed in this industry were union members). Within the education sector, there were marked differences. Only 25.8 percent of those in the tertiary sector were unionists, while 47.4 percent of those employed in pre-schools and schools were in a union (ABS 2008a). Was this difference due to the fact that the National Tertiary Education Union (NTEU) and the other unions covering the tertiary sector were poor organisers? Or was it due to differences in product and labour market factors? The latter seems more likely. The tertiary sector has seen a proliferation of private providers, and a significant increase in contingent employment. These trends have been much less pronounced in primary and secondary school education. Similarly, in the transport sector, density levels in 2007 were much lower in road transport (24.2 percent) than in rail transport (69.5 percent). Again, this variation is more likely to be explained through reference to the innate difficulty in maintaining effective regulation under a system of enterprise bargaining in road transport - where there are few barriers to restrict new entrants - than to the 'organising' failings of the Transport Workers Union. 
While, overall, the Australian union movement has suffered a catastrophic loss of support in both the private and public sector there are some notable exceptions to the rule. In the public sector, unions covering fire-fighters and police still command the loyalty of virtually all the workers covered by their rules. As noted above, primary and secondary teaching, the railways and nursing have also largely avoided the general fate. Why is this? The factors that guarantee continued union strength are perhaps most clearly delineated in emergency services. Unlike unions in other occupations, those covering police and fire-fighters have avoided the practice of workplace bargaining. Centralised bargaining, and standardised employment outcomes, prevail. Industrially, the strength of the emergency service unions rests on a traditional craft model. Only those who undertake a strict training regime are entitled to membership. Attempts to expand the use of contingent labour (part-timers, casuals, contractors) have been fiercely resisted. The principal concern of such unions (and of their members) is that of maintaining strict labour market control over entry into these professions (Bowden, 2008; Fleming and Marks, 2004).

If we consider the factors that have contributed to general union decline in Australia, as well as those areas that have either totally or partially resisted this process of decline, two key lessons emerge. First, union decline is clearly associated with structural changes in the economy, and a growth in contingent employment in most industries and occupations, as well as the process of industrial relations deregulation. The combined effect of these changes has eroded union capacity to regulate the nature of the labour supply into a given industry or occupation. It has also been associated with a widespread collapse of standardised employment conditions across industries and occupations.

Second, it is evident that where such changes have not occurred (or have occurred to a limited extent), the process of union decline has been fully or partially mitigated. This, in turn, suggests that a strategy centred upon workplace activism is ill-suited to the problems facing Australian unions. Instead, unions need to consider strategies that will assist with the re-regulation of labour markets. In part, such strategies require major changes to labour laws so as to favour a more centralised approach to the fixation of employment conditions, including 'pattern bargaining' (bargaining that binds all employers in an industry rather than individual enterprises). In mid-2009, support for pattern bargaining and 'industry-wide' campaigns had again become declared ACTU policy, as the union movement retreats from its earlier advocacy of enterprise bargaining (Hannan 2009b: 1). The Rudd Labor Government, however, fiercely opposes such an approach. Even if more favourable legislation was to be passed the task of rebuilding a capacity for industry-wide campaigns will be difficult. Not only are unions in a weakened state, most employers and workers have now become conditioned to bargaining at the workplace or enterprise level.

In short, the situation for unions remains dire. There is certainly no real indication that the organising model provides unionism with the capacity to reverse the effects of the historic forces - deep seat structural changes in the economy, an embrace of neo- 
liberal models of economic and industrial deregulation by all major political parties, and dramatic changes in the organisation of work - that have undercut its influence in recent years.

\section{Conclusion}

At a time when union membership in Australia is approaching levels last seen in the nineteenth century, no-one who is interested in union survival will argue against a greater organising focus. Union renewal has always depended on successful organising. As the Webbs (1902: 463) observed, 'the branches of a Labour Union are, for one reason or another, always crumbling away; and the total membership is only maintained by perpetually breaking fresh ground.'

What is contentious about the organising model is assumption that a strategy based around workplace organising and bargaining, rather than one which focuses upon occupation or industry-wide regulation, holds the key to union survival. In 1998, in reviewing arguments that Australian union growth depended upon a workplace orientation, Joe Isaacs (1998: 712) concluded that:

if the object of union growth is to secure a better economic and social deal for workers rather than growth for its own sake, it is far from clear whether workers generally ... will necessarily be advantaged by decentralised wage determination. Indeed, the available evidence suggests the opposite.

This article concurs with Isaacs' scepticism. There is no evidence to suggest that the adoption of the organising model, and a greater workplace focus, has delivered Australian unions any substantial benefit. Membership and union density have continued to fall. The standardised pattern of employment conditions that characterised Australia twenty years ago has broken down. This has exposed even the best organised sections of the union movement to destruction as employment is outsourced to lower-cost suppliers. If this pattern is to be reversed then unions will need to again a strong measure of industrial regulation over occupational labour markets; a process that can only occur through centralised campaigns that make industry-wide objectives the central focus of their efforts. 


\section{References}

Alexander, M, Green, R and Wilson, A (1998) 'Delegate Structures and Strategic Unionism: Analysis of Factors in Union Resilience.' Journal of Industrial Relations, 40(4): 663-689.

Australian Bureau of Statistics. 1948-1975. Labour Reports, Cat. No. 6101.0, Canberra: Australian Bureau of Statistics.

Australian Bureau of Statistics. 1999. Employee Earnings, Benefits and Trade Union Membership, Cat. No. 6310.0. Canberra: Australian Bureau of Statistics.

Australian Bureau of Statistics. 2007a. Trade Union Membership Time Series, 19902006, Cat. No. 63100TS0001. Canberra: Australian Bureau of Statistics.

Australian Bureau of Statistics. 2007b. Employee Earnings, Benefits and Trade Union Membership, Cat. No. 6310.0. Canberra: Australian Bureau of Statistics.

Australian Bureau of Statistics. 2008a. Employee Earnings, Benefits and Trade Union Membership, Cat. No. 6310.0. Canberra: Australian Bureau of Statistics.

Australian Bureau of Statistics. 2009. Employee Earnings, Benefits and Trade Union Membership, Cat. No. 6310.0. Canberra: Australian Bureau of Statistics.

Australian Bureau of Statistics. 2008b. 2008: Year Book Australia, Cat. No. 1301.0. Canberra: Australian Bureau of Statistics.

Australian Bureau of Statistics. 2008c. Industrial Disputes: Time Series, 1985-2007, Cat. No. 6321.0.55.001. Canberra: Australian Bureau of Statistics.

Banks, A and Metzger, J (1989) 'Participating in Management: Union Organizing on a New Terrain.' Labor Research Review, 14(1): 1-55.

Barton, R, Snell, D and Fairbrother, P (2008) 'Unions in the Twenty-First Century and Beyond: The Multiple Dimensions of Union Renewal.' Unions in the TwentyFirst Century and Beyond: The Environment, Politics and Education Conference (Melbourne, 17-18 November), publisher???

Bowden, B (2003) 'Regulating Outsourcing: The Use of Contractors on the Central Queensland Coalfields, 1974-2003.' Labour and Industry, 14(1): 41-57.

Bowden, B (2008) Against All Odds: The History of the United Firefighters Union in Australia. Sydney: Federation Press.

Bronfenbrenner, K (1997) 'The Role of Union Strategies in NLRB Certification Elections.' Industrial and Labor Relations, 50(2): 195-212.

Bronfenbrenner, K (2003) 'The American Labor Movement and the Resurgence in Union Organizing' in Peter Fairbrother and Charlotte A B Yates, eds.. Trade Unions in Renewal: A Comparative Study, London: Continuum: 32-50.

Bronfenbrenner, K, Friedman, S, Hurd, RW, Osward, R A and Seeber, R A (1998) 'Editor's introduction' in Kate Bronfenbrenner, Shelton Friedman, RRichard W Hurd, Rudolph A Oswald and Ronald L Seeber, eds.. Organizing to Win: New Research on Union Strategies. Ithaca and London, IRL Press: 1-8.

Bureau of Labor Statistics. 2008. Union Members in 2007. Washington (DC): United States Department of Labor. 
Callus, R, Moorehead, A, Cully, M and Buchanan, J (1991) Industrial Relations at Work: the Australian Workplace Industrial Relations Survey. Canberra: Australian Government Publishing Service.

Conrow, T (1991) 'Contract Servicing from an Organizing Model: Don't Bureaucratize, Organize!’ Labor Research Review, 17(1): 45-59.

Cooper, R (2001) 'Getting Organised? A White Collar Union Responds to Membership Crisis.’ Journal of Industrial Relations, 43(4): 422-37.

Cooper, R (2003) 'Peak Council Organising at Work: ACTU Strategy 1994-2000.' Labour and Industry, 14(1): 1-15.

Dabscheck, B (2001) 'The Slow and Agonising Death of the Australian Experiment with Conciliation and Arbitration.’ Journal of Industrial Relations, 43(3): 277-93.

Danford A, Richardson, M and Upchurch, M (2003) New Unions, New Workplaces: A Study of Union Resilience in the Restructured Workplace. London and New York: Routledge,.

Deery, J and Plowman, D (1991) Australian Industrial Relations, $3^{\text {rd }}$ edition. Sydney: McGraw-Hill.

Di Milia, L and Bowden, B (2007) 'Unanticipated Safety Outcomes: Shiftwork and Drive-in, Drive-out Workforces in Queensland's Bowen Basin.' Asia Pacific Journal of Human Resources, 45(1): 113-23.

Fairbrother, P and Stewart, P (2003) 'The Dilemmas of Social Partnership and Union Organization: Questions for British Trade Unions' in Peter Fairbrother and Charlotte A B Yates, eds.. Trade Unions in Renewal: A Comparative Study, London: Continuum: 158-79.

Fletcher, B and Hurd, R (1998) 'Beyond the Organizing Model: The Transformation Process in Local Unions’ in Kate Bronfenbrenner, Shelton Friedman, RRichard W Hurd, Rudolph A Oswald and Ronald L Seeber, eds.. Organizing to Win: New Research on Union Strategies. Ithaca and London, IRL Press: 39-53.

Fairbrother, P and Yates, C (2003) 'Unions in Crisis, Unions in Renewal?' in Peter Fairbrother and Charlotte A B Yates, eds.. Trade Unions in Renewal: A Comparative Study, London, Continuum: 1-31.

Fleming, J and Marks, M (2004) “"Reforms or Resisters”: The State of Police Unions in Australia.’ Employment Relations Record, 14(1): 1-14.

Gahan, P (1996) 'Did Arbitration Make for Dependent Unionism? Evidence from Historical Case Studies.’ Journal of Industrial Relations, 38(4): 648-98.

Gahan, P and Bell, S (1999) 'Union Strategy, Membership Orientation and Union Effectiveness: An Exploratory Analysis.’ Labour and Industry, 9(3): 5-30.

Griffin, G (2007) 'Australian Unions: Still in Crisis' in Craig Phelan, ed., Trade Union Revitalisation: Trends and Perspectives in 34 Countries. Bern, Peter Lang: 547-61.

Griffin, G and Svensen, S (1996) 'The Decline of Australian Union Density - A Survey of the Literature.' Journal of Industrial Relations, 33(4): 505-547.

Griffin, G, Small, R and Svensen, S (2003) 'Trade Union Innovation, Adaptation and Renewal in Australia: Still Searching for the Holy Membership Grail' in Peter 
Fairbrother and Charlotte A B Yates, eds.. Trade Unions in Renewal: A Comparative Study. London, Continuum: 78-101.

Griffin, G and Moors, R (2004) 'The Fall and Rise of Organising in a Blue-Collar Union.’ Journal of Industrial Relations, 46(1): 39-52.

Hannan, E (2009a) 'Union Boost under Rudd.’ Australian, 14 September: 1, 6.

Hannan, E (2009b) 'Unions Press for Demands to be Met.' Australian, 1 June: 1,4.

Haynes, P, Boxall, P, and Mackay K (2006) “"Union Reach”, the "Representation Gap” and the Prospects for Unionism in New Zealand.' Journal of Industrial Relations, 48(2): 193-216.

Heery, E, Simms, M, Simpson D, Delbridge, R and Salmon, J (2000) 'Organizing Unionism comes to the UK.' Employee Relations 22(1): 38-57.

Howard, W A (1977) 'Trade Unions in the Context of Union Theory.' Journal of Industrial Relations, 19(3): 255-73.

Howard, W A (1983) ‘Australian Trade Unions and the Arbitration System’ in Brian W Head, ed., State and Economy in Australia. Melbourne, Oxford University Press: 238-51.

Hurd, R (2004) 'The Failure of Organizing, the New Unity Partnership, and the Future of the Labour Movement.' Journal of Labor and Society, 8: 5-25.

Hurd, R W (2006) 'The Rise and Fall of the Organizing Model in the US' in Mark Harcourt and Geoffrey Wood, eds.. Trade Unions and Democracy: Strategies and Perspectives. New Brunswick (NJ), Transaction Publishers: 191-210.

Isaacs, J (1998) 'Australian Labour Market Issues: An Historical Perspective.' Journal of Industrial Relations 40(4): 690-715.

Juravich, T and Bronfenbrenner, K (1998) 'It Takes More than House Calls: Organizing to Win with a Comprehensive Union-building Strategy' in Kate Bronfenbrenner, Shelton Friedman, Richard Hurd, RA Oswald and Ronald L Seeber, eds.. Organizing to Win: New Research on Union Strategies. Ithica and London, IRL Press: 19-36.

Katz, H C and Sabel, C F (1985) 'Industrial Relations and Industrial Adjustment in the Car Industry.’ Industrial Relations, 24(3): 295-315.

Kochan, T A, Katz, H C and McKersie, R B (1986) The Transformation of American Industrial Relations. New York: Basic Books.

Mathews, J (1989) Age of Democracy: The Politics of Post-Fordism. Melbourne: Oxford University Press.

Maraschai, P M (2006) 'Innovation and Adaption: Contrasting Efforts to Organize Home Care Workers in Four States.’ Labour Studies, 31(1): 25-49.

Mercer, S and Notley, R (2008) Trade Union Membership 2007. London, United Kingdom Department for Business Enterprise and Regulatory Reform.

Ness, I (1998) 'Organizing Immigrant Communities: UNITE's Workers Center Strategy' in Mark Harcourt and Geoffrey Wood, eds., Trade Unions and Democracy: Strategies and Perspectives. New Brunswick (NJ), Transaction Publishers: 87-101. 
Oxenbridge, S (2003) 'A Story of Crisis and Change: The Services and Food Workers Union of Aotearoa' in Peter Fairbrother and Charlotte A B Yates, eds.. Trade Unions in Renewal: A Comparative Study. London, Continuum: 135-57.

Perlman, S and Taft, P in association with Commons, J (1966) The History of Labour in the United States. New York, Augustus M. Kelly, vol. 4.

Peetz, D (1998) Unions in a Contrary World: the Future of the Australian Trade Union Movement. Melbourne: Cambridge University Press.

Peetz, D (2006) Brave New Work Place: How Individual Contracts are Changing Our Jobs. Sydney: Allen and Unwin.

Peetz, D, Pocock, B and Houghton, C (2007) 'Organizers' Roles Transformed? Australian Union Organizers and Changing Union Strategy.’ Journal of Industrial Relations, 49(2): 151-166.

Probert, B and Ewer, P (2003) 'A Near Death Experience: One Union Fights for Life' in Peter Fairbrother and Charlotte A B Yates, eds.. Trade Unions in Renewal: A Comparative Study. London, Continuum: 102-16.

Pocock, B (1998) 'Institutional Sclerosis: Prospects for Trade Union Transformation.' Labour and Industry, 9(1):17-36.

Santamaria, B (1981) Santamaria: Against the Tide, Melbourne: Cambridge University Press.

Schenk, C (2003) 'Social Movement Unionism: Beyond the Organizing Model', in Peter Fairbrother and Charlotte A B Yates, eds.. Trade Unions in Renewal: A Comparative Study. London, Continuum: 244-62.

Statistics Canada. 2007. Perspectives on Labour and Income: Unionization. Ottawa: Statistics Canada.

Turner, L (1991) Democracy at Work: Changing World Markets and the Future of Labor Unions. Ithica and London: Cornell University Press.

Vandenheuvel, A and Wooden, M (1995) 'Self-Employed Contractors in Australia: How Many and Who are They.' Journal of Industrial Relations, 37(2): 263-80.

Voss, K and Sherman, R (2003) 'You Just Can’t Do it Automatically: The Transition to Social Movement Unionism in the United States' in Peter Fairbrother and Charlotte A B Yates, eds.. Trade Unions in Renewal: A Comparative Study. London, Continuum: 51-77.

Walsh, P and Crawford, A (2003) 'From Organizational Breadth to Depth? New Zealand's Trade Unions under the Employment Contracts Act' in Peter Fairbrother and Charlotte A B Yates, eds.. Trade Unions in Renewal: A Comparative Study. London, Continuum: 117-34.

Webb, S and Webb, B (1902) The History of Trade Unionism. London: Longmans Green.

Webb, S and Webb, B (1920) Industrial Democracy. London: Seaham Division of Labour Party.

Wooden, M (1999), 'Union Amalgamation and the Decline in Union Density.' Journal of Industrial Relations, 41 (1): 35-52. 